\title{
Resolution of wheat-dependent exercise induced anaphylaxis-case report
}

\author{
Lana A Rosenfield', Chrystyna Kalicinsky ${ }^{2 *}$ \\ From Canadian Society of Allergy and Clinical Immunology Annual Scientific Meeting 2010 \\ Victoria, Canada. 3-6 November 2010
}

\section{Background}

The natural history of Wheat Dependent Exercise Induced Anaphylaxis (WDEIA) is not well defined. In IgE mediated, non exercise dependent, wheat allergy in children, the approximate age for resolution is 6.5 years with rare persistence into adolescence [1]. We report a case of resolution of WDEIA in an adult.

\section{Case report}

A 62 year old male was assessed in 2006 with a 3-4 year history of recurrent acute urticaria. A month prior to consultation he developed anaphylaxis.

No consistent trigger was identified, therefore a covariable with food, such as exercise, was suspected.

Skin prick testing (SPT) to foods ingested within 4 hours of anaphylaxis was positive to wheat flour and negative to wheat extract (WE) (Allergy Canada), peanut, egg, cow's milk, cod, pickerel, salmon, whitefish, clam, and potato. Wheat products were tolerated daily, therefore WDEIA was suspected. Strict wheat avoidance was advised and epinephrine autoinjector prescribed.

4-6-12 months later he was asymptomatic with wheat avoidance. SPT was negative to oat, rye, corn flour.

In 2008 and 2009 SPT was WE negative and flour positive.

In 2010 he reported eating wheat products, followed by exercise, with no reactions $>6$ months. SPT was negative to WE and flour.

\section{Results}

This patient demonstrates WDEIA which resolved four years after diagnosis. The patient is asymptomatic despite

\footnotetext{
* Correspondence: CKalicinsky@exchange.hsc.mb.ca

${ }^{2}$ Section of Clinical Immunology and Allergy, University of Manitoba,

Winnipeg, Canada GC319-820 Sherbrook St. Winnipeg, Mb, R3A 1R9

Full list of author information is available at the end of the article
}

wheat ingestion followed by exercise. SPT to wheat flour, which was positive previously, is now negative.

\section{Conclusion}

This is the first case of WDEIA resolution reported. History plus SPT with wheat flour was used to diagnose WDEIA, and to confirm its resolution.

\section{Author details}

${ }^{1}$ Faculty of Medicine, University of Manitoba, Winnipeg, Canada. ${ }^{2}$ Section of Clinical Immunology and Allergy, University of Manitoba, Winnipeg, Canada GC319-820 Sherbrook St. Winnipeg, Mb, R3A 1R9.

Published: 4 November 2010

\section{Reference}

1. Keet C, Matsui E, Dhillon G, Lenehan P, Paterakis M, Wood R: The Natural History of Wheat Allergy. Ann Allergy Asthma Immunol 2009, 102:410-415.

doi:10.1186/1710-1492-6-S2-P30

Cite this article as: Rosenfield and Kalicinsky: Resolution of wheatdependent exercise induced anaphylaxis-case report. Allergy, Asthma \& Clinical Immunology 2010 6(Suppl 2):P30.

Submit your next manuscript to BioMed Central and take full advantage of:

- Convenient online submission

- Thorough peer review

- No space constraints or color figure charges

- Immediate publication on acceptance

- Inclusion in PubMed, CAS, Scopus and Google Scholar

- Research which is freely available for redistribution 